\title{
Genotypic mapping of HPV and assessment of EBV prevalence in endocervical lesions
}

\author{
J J O'Leary, R J Landers, M Crowley, I Healy, W F Kealy, J Hogan, C Cullinane, \\ P Kelehan, C T Doyle
}

Nuffield Department of Pathology and Bacteriology, University of Oxford, UK

J J O’Leary

Department of Pathology, University of Sheffield, UK R J Landers

Department of Pathology, University College Cork, Ireland $M$ Crowley I Healy

W F Kealy

J Hogan

C T Doyle

Department of Pathology, St James' University Teaching Hospital, Leeds, UK C Cullinane

Department of Pathology, The National Maternity Hospital, Dublin, Ireland

P Kelehan

Correspondence to: Dr O'Leary, Department of Pathology, Cornell University Medical College, Cornell Medical Center, The New York Hospital, New York, NY 10021, USA.

Accepted for publication 2 September 1997

\begin{abstract}
Aims-To examine the prevalence of human papillomavirus (HPV) and Epstein-Barr virus (EBV) in low grade glandular intraepithelial lesions of the cervix, adenocarcinoma with high grade glandular intraepithelial lesions combined, and adenocarcinomas; and to perform a genotyping mapping analysis of endocervical carcinomas to determine the extent of HPV infections in such lesions.

Material-Archival paraffin wax embedded material from the files of the departments of pathology, National Maternity Hospital, Dublin, and University College Cork, Ireland.

Methods-HPV prevalence was examined using type specific HPV PCR, general primer HPV PCR (pan HPV screen), nonisotopic in situ hybridisation (NISH), and PCR in situ hybridisation (PCR-ISH). In situ hybridisation was performed using fluorescein labelled oligonucleotide cocktail for eber transcripts of EBV. Genotypic analysis was performed, in all cases where possible, using a grid system

Results-HPV 16 and 18 were predominantly identified in low grade glandular intraepithelial lesions, high grade glandular intraepithelial lesions, and adenocarcinomas, with HPV prevalence increasing with grade of dysplasia. EBV was only identified in subepithelial lymphocytes in a minority of cases. No link could be shown between HPV and EBV in endocervical lesions. HPV infection was not clonal in endocervical cancer and coexistent adjacent cervical intraepithelial neoplasia, where present, tended to show a similar HPV type.

Conclusions-The restriction of HPV types 16 and 18 to endocervical lesions suggests that their effect is restricted and specific to endocervical mucosa, but the mechanism of interaction is currently unknown.
\end{abstract}

(F Clin Pathol 1997;50:904-910)

Keywords: human papillomavirus; Epstein-Barr virus; endocervical lesions

The relative frequency of adenocarcinoma of the cervix has increased to between $12.7 \%$ and $18.5 \%$ in recent years. ${ }^{1-3}$ In contrast, the incidence of invasive squamous cell carcinoma has decreased, largely because of cervical screening, which has little apparent effect on endocervical lesions.

Criteria for the diagnosis of glandular intraepithelial neoplasia and adenocarcinoma in situ of the cervix are controversial. Such lesions are often focal and quite superficial and therefore are not commonly diagnosed. More extensive multicentric lesions, although more easy to see, are often quite difficult to differentiate from adenocarcinoma of the cervix.

Endocervical glandular intraepithelial neoplasia is diagnosed by the presence of endocervical glands, the epithelium of which shows intraluminary papillary projections with focal cribriform or bridging patterns. Basophilia of the cytoplasm with nuclear atypia and pseudostratification are usually prominent. Categorisation into low and high grade lesions has been suggested, but there is considerable overlap between the high grade designation and adenocarcinoma in situ (see below). In this paper, the low and high grade categorisation formula is adopted, taking into account the virtual similarity between high grade glandular intraepithelial lesions and adenocarcinoma in situ.

Adenocarcinoma in situ again shows basophilic cytoplasm, significant nuclear atypia, frequent mitotic figures, and nuclear pseudostratification over several layers. Papillary projections are prominent and the architecture complex, but stromal invasion is not seen.

The precise biological significance of less severe endocervical lesions, termed atypical endocervical hyperplasia of the columnar endocervix, has not been well established. Although the clinical and histological features of microinvasive squamous cell carcinoma are well defined, those of its endocervical counterpart are not.

The potential for undifferentiated cells in Mullerian tissues to differentiate along several lines leads ultimately to a wide range of tumour types, among which are endometrioid or papillary serous adenocarcinoma of the cervix.

The most frequent member of this group is represented by endocervical adenocarcinoma, the most well differentiated form called "adenoma malignum."4 5 Papillary serous carcinoma of the cervix typically grows in a papillary fashion, with a proportion differentiating along tubal lines resembling serous carcinoma of the ovary. Endometrioid carcinoma can arise in foci of cervical endometriosis but more commonly arises from undifferentiated endocervical reserve cells. Clear cell carcinoma is morphologically identical to clear 
cell carcinoma of the endometrium; these are tumours of Müllerian duct origin, some of which occur in young women exposed prenatally to diethylstilboestrol. ${ }^{6}$ Mesonephric adenocarcinomas are extremely rare neoplasms and are histologically similar to clear cell adenocarcinomas of Müllerian type. ${ }^{7}$ Enteric adenocarcinomas of intestinal type occur very rarely in the cervix. ${ }^{8}$ Adenosquamous carcinomas are also found, some of which having a "glassy cell" morphology. ${ }^{9}$

Over 70 types of human papillomavirus (HPV) are now described, and there is a strong association between "low" and "high" risk HPV types and the development of premalignant and malignant squamous epithelial lesions of the cervix. HPV 6 and 11 are considered to be low risk types, associated with condylomas and cervical intraepithelial neoplasia (CIN) grade 1. HPV types 16, 18, 31, $33,35,39,51$ are high risk types related to the development of high grade CIN (CIN 2 and 3) and invasive squamous cell carcinoma. HPV has also been detected in glandular intraepithelial neoplasia, adenocarcinoma in situ, and adenocarcinoma of the endocervix. Prevalence rates vary but approximately $79 \%$ of adenocarcinoma in situ lesions and $43 \%$ of adenocarcinomas contain HPV, predominantly of types 16 and $18 .^{10-12}$ It seems reasonable therefore to postulate that similar cellular events are operational in endocervical lesions as in CIN and invasive squamous cell carcinoma.

The idea of a sexually transmittable infectious carcinogen as the dominant factor in the pathogenesis of cervical neoplasia has received widespread attention. ${ }^{12}{ }^{13}$ Possible agents include herpes virus 2 ( $\mathrm{HSV} 2$ ), Chlamydia trachomatis, HPV, cytomegalovirus, and more recently, Epstein-Barr virus (EBV). ${ }^{14}$ The association between human papillomavirus and squamous cell cervical neoplasia is well known, although its role in endocervical neoplasia is still inconclusive. ${ }^{13}$ The role of synergistic/carcinogenic factors such as two or more viruses interacting, possibly at different stages of cervical carcinogenesis, has previously been considered by zur Hausen. ${ }^{15}$ EBV, an oncogenic herpes virus, has been suggested as a possible viral cofactor. EBV has a ubiquitous distribution, causing widespread and largely asymptomatic infection worldwide. The virus is known to be associated with three lymphoproliferative disorders of $B$ cell origininfectious mononucleosis, Burkitt's lymphoma, and lymphomas - in immunocompromised patients. An association between EBV and undifferentiated nasopharyngeal carcinoma has been documented previously. ${ }^{16}{ }^{17}$ Indeed other carcinomas, for example, tonsil, tongue, larynx, and thymus, have also shown an association with EBV. ${ }^{18-22}$

Sixbey et al have produced in vitro and in vivo evidence of EBV viral replication in the cervix. ${ }^{23}$ In particular, they have shown that cultured ectocervical epithelial cells can be infected with EBV. ${ }^{23}$ Using cultures of ectocervical epithelium, they also have demonstrated that EBV can binding to epithelial cells. Cultured ectocervical epithelial cells react with several monoclonal antibodies specific for the EBV receptor on B lymphocytes, strongly suggesting expression of a functional EBV receptor on cervical epithelial cells. To our knowledge, no such data exist in relation to endocervical mucosa. Similar observations have been seen in other stratified squamous epithelia, for example, pharynx and tongue. ${ }^{24}$ In addition, late EBV DNA viral antigens have been identified in exfoliating cells, but not in attached epithelial monolayer culture cells, suggesting an association between viral replication and the stage of epithelial differentiation. Infectious EBV capable of transforming B lymphocytes have been isolated in cervical washings from women recovering from infectious mononucleosis, and from EBV positive individuals who have had no clinical or serological evidence of acute EBV infection. ${ }^{25}$ It appears that the cervix may be a site of chronic viral shedding in a manner similar to the nasopharynx.

In this study, we examine the prevalence of HPV and EBV in three cohorts of endocervical lesions-low grade glandular intraepithelial lesions, adenocarcinoma with adjacent high grade glandular intraepithelial lesions/adenocarcinoma in situ, and pure adenocarcinomas - to investigate any synergistic relation between HPV and EBV in the pathogenesis of endocervical carcinoma. In addition, we performed an HPV genotypic mapping analysis of the adenocarcinoma cohort, to establish the extent of HPV infection in such lesions. In genotypic mapping, selective fields are analysed within a tumour in order to delineate the extent and clonality of a particular genetic marker (that is, the presence of HPV, ras, p53 mutations, and so on).

\section{Methods}

MATERIALS

Archival paraffin wax embedded material was retrieved from the files of the departments of pathology, National Maternity Hospital, Dublin, and University College Cork, Ireland. Ten low grade glandular intraepithelial lesions, eight high grade glandular intraepithelial lesions and adenocarcinoma combined, and 11 adenocarcinomas of the cervix were examined. Coexistent areas of CIN were also assessed. HPV prevalence was examined using type specific HPV polymerase chain reaction (PCR), general primer HPV PCR (pan HPV screen), non-isotopic in situ hybridisation (NISH), and PCR in situ hybridisation (PCR-ISH). Genotypic analysis was performed (in all cases where possible) using a grid system (1-4), as illustrated in fig 1 . Tissue was microdissected from each of the areas designated and analysed by solution phase PCR.

\section{HPV IN SITU HYBRIDISATION}

Three $5 \mu \mathrm{m}$ sections (selected from different areas of the tumour) were cut onto APES coated glass slides (PH106, C A Hendley, Essex, UK).

Tissues were dewaxed in xylene and rehydrated through a graded alcohol series. Proteolytic digestion was carried out using $0.5 \mathrm{mg} / \mathrm{ml}$ 


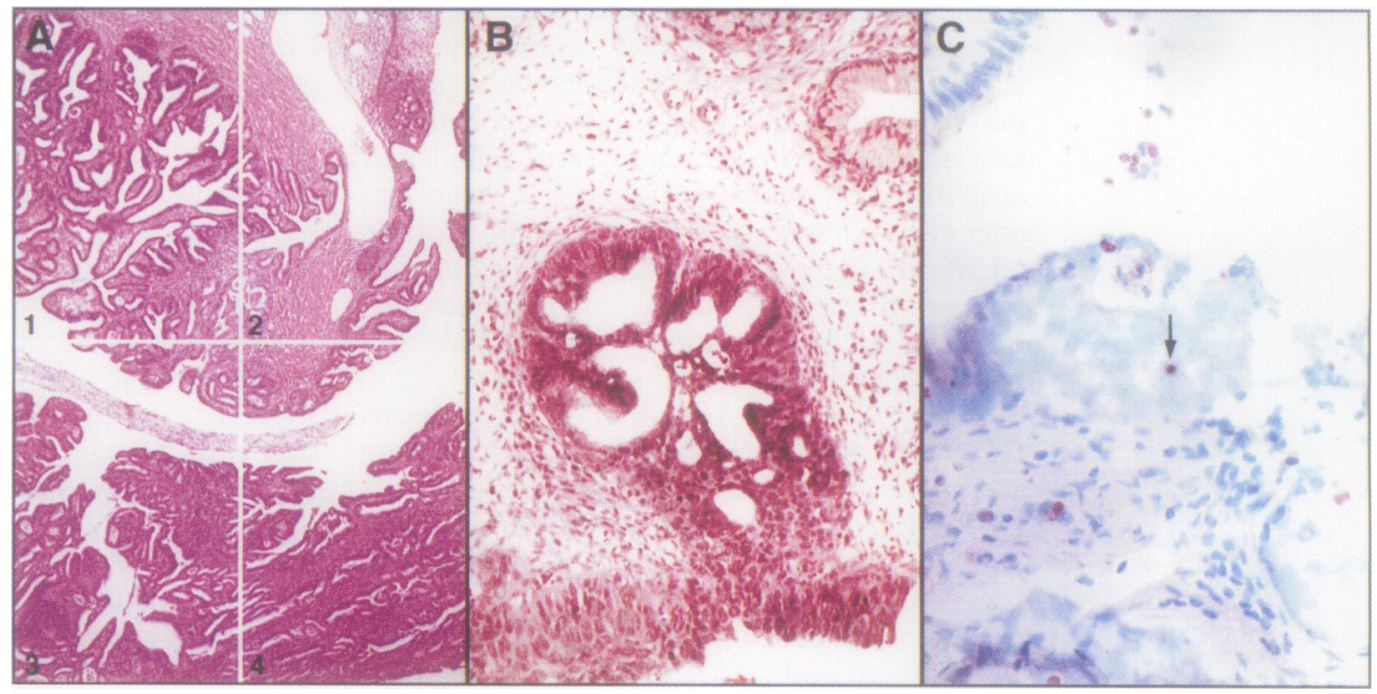

Figure 1 (A) Genotypic mapping experiment in an endocervical adenocarcinoma, based on a grid system, divided into areas 1-4. (B) Adenocarcinoma in situ in an endocervical gland. (C) HPV 16 NISH in adenocarcinoma in situ showing a discrete nuclear signal.

proteinase $\mathrm{K}$ in proteinase $\mathrm{K}$ buffer $(50 \mathrm{mM}$ Tris $\mathrm{HCl} \mathrm{pH} \mathrm{7.6,} 5 \mathrm{mM}$ EDTA) at $37^{\circ} \mathrm{C}$ for 10 minutes. Slides were immersed in phosphate buffered saline (PBS) containing $2 \mathrm{mg} / \mathrm{ml}$ glycine for five minutes and washed in PBS for a further five minutes. For alkaline phosphatase detection, slides were immersed in $20 \%$ (vol/vol) aqueous acetic acid at $4^{\circ} \mathrm{C}$ for $15 \mathrm{sec}-$ onds. For peroxidase detection, slides were immersed in 3\% sodium azide/hydrogen peroxide to abolish endogenous peroxidase activity. Slides were then washed in PBS for five minutes. A postfixation step was not carried out. Dehydration of the sections then took place through graded alcohols to water.

Cloned HPV probes $(6,11,16,18,31,33)$ (genital types; gifts of Harald Zur Hausen) were labelled with biotin or digoxigenin using a standard nick translation protocol. ${ }^{26}$ Probes were prepared at $200 \mathrm{ng} / \mathrm{ml}$.

The hybridisation buffer contained $2 \times$ SSC (sodium chloride/sodium citrate), 5\% dextran sulphate, $0.2 \%$ dried milk powder containing no vegetable extracts, and $50 \%$ formamide. Approximately 10-20 ng of the appropriate probe in hybridisation buffer was applied to the centre of each PH106 slide well. Gel bond (FMC Bioproducts, Rockland, Maine, USA) cut to cover slip size, was placed hydrophobic side down over each tissue section and sealed in place with nail varnish. Sections were denatured at $90^{\circ} \mathrm{C}$ for 10 minutes. After denaturation, slides were transferred to a humidified box and incubated at $37-42^{\circ} \mathrm{C}$ overnight. Following hybridisation, the gel bond was removed with a scalpel blade and the slides immersed in $2 \times$ SSC at room temperature.

Medium stringency posthybridisation washings were initially applied using $2 \times$ SSC at $60^{\circ} \mathrm{C}$ for 20 minutes, followed by $0.2 \times$ SSC for $42^{\circ} \mathrm{C}$ at 20 minutes, then $0.1 \times$ SSC at room temperature for five minutes, and $2 \times$ SSC at room temperature for five minutes. Higher stringency washes included $0.2 \times \mathrm{SSC}$ at $55^{\circ} \mathrm{C}$ and $60^{\circ} \mathrm{C}$ for 10 minutes and $0.1 \times$ SSC at room temperature, $42^{\circ} \mathrm{C}$ and $55^{\circ} \mathrm{C}$.
The hybridisation signal was detected using one step, two step, or three step techniques as described previously. ${ }^{26}$ Colorimetric detection was achieved using a NBT/BCIP substrate for alkaline phosphatase or aminoethylcarbazole (Zymed kit for peroxidase, California, USA). ${ }^{26}$ Sections were counterstained with $2 \%$ methyl green for alkaline phosphatase detection or haematoxylin for the peroxidase detection system.

Tissue controls for NISH included HPV positive cervical wart, and myocardium (negative for HPV). Reaction controls included hybridisation buffer on its own, biotin/ digoxigenin labelled plasmid sequences (pBR322), and irrelevant probe (herpes zoster virus, HZV). Labelled human placental DNA was used to check hybridisation efficiency.

Detection controls included omitting primary or secondary antibody steps and addition of the colorimetric substrate only.

\section{EBER-ISH}

Tissue dewaxing was carried out as above. In situ hybridisation was performed using a fluorescein labelled oligonucleotide cocktail for eber transcripts of EBV: $20 \mu \mathrm{l}$ of probe hybridisation solution were incubated on the tissue sections for two hours at $37^{\circ} \mathrm{C}$; slides were then washed in Tris buffered saline containing $0.1 \%$ Triton $\mathrm{X}-100$ for three minutes three times. Detection was achieved using the Novocastra in situ hybridisation detection kit, following the recommended method for hybrid detection.

\section{SOLUTION PHASE PCR}

HPV DNA sequences were derived from the EMBL genetic sequence database. HPV E6 sequences which remain intact following viral DNA integration were chosen. ${ }^{27}$ Oligonucleotide primers were synthesised on a Perkin Elmer Applied Biosystems DNA synthesiser (Perkin Elmer, Cheshire, UK), deprotected, and stored in liquid ammonia at $-20^{\circ} \mathrm{C}$. During oligo synthesis, a biotin reporter 
molecule with a 15 carbon atom linker arm was added to the 5 ' end of the oligonucleotide probe, which was subsequently used as an internal probe to confirm product specificity. The nucleotide sequence of the primers were as previously described. ${ }^{27}$

General HPV primers (which identify sequenced and unsequenced human papillomaviruses) were also used for a pan HPV screen, unrestricted by the type specific viruses chosen. These were as previously described. ${ }^{28}$

For EBV amplification EBNA-1 primers were used-primer 1: ATCGTGGTCAAGGAGGTTCC; primer 2: ACTCAATGGTGTAAGACGAC - and probed with a 30 mer 5' biotin labelled probe: AGAGCTCTCCTGGCTAGGAGTCACGTAGAA, using Southern analysis.

Ten $5 \mu \mathrm{m}$ sections were cut and placed in sterile Eppendorf tubes. Strict anticontamination protocols were adopted. Nucleic acid extraction was carried out using proteinase $K$ $(0.1-0.5 \mathrm{mg} / \mathrm{ml})$ in proteinase $\mathrm{K}$ buffer (100 mM NaCl, $10 \mathrm{mM}$ Tris $\mathrm{HCl}, 25 \mathrm{mM}$ EDTA, $0.5 \%$ sodium dodecyl sulphate, $\mathrm{pH}$ 8.4). Proteinase $\mathrm{K}$ incubation was carried out for three to five days at $37^{\circ} \mathrm{C}$ with adequate mixing of samples. Proteinase $\mathrm{K}$ inactivation was then carried out at $94^{\circ} \mathrm{C}$ for 10 minutes. DNA was purified using a standard phenol chloroform isoamyl alcohol technique. Nucleic acid was precipitated using $3 \mathrm{M}$ sodium acetate and ice cold ethanol.

For genotypic mapping areas were selected as in fig 1 and microdissected using a sterile blade. DNA was extracted as above.

For type specific HPV PCR, the PCR solution consisted of PCR buffer $(50 \mathrm{mM}$ $\mathrm{KCl}, 10 \mathrm{mM}$ Tris $\mathrm{HCl} \mathrm{pH} 8.3,1.5 \mathrm{mM}$ $\mathrm{MgCl}_{2}, 0.01 \%$ gelatine, $200 \mu \mathrm{M}$ of each dNTP, $1.0 \mu \mathrm{M}$ of each primer, 2.5 units of AmpliTaq DNA polymerase and $100 \mathrm{ng}$ of DNA template). Samples were then subjected to 40 cycles of PCR in a Perkin Elmer 480 DNA thermocycler. Cycling parameters were as follows: $94^{\circ} \mathrm{C}$ for one minute, followed by $94^{\circ} \mathrm{C}$ for one minute, $55^{\circ} \mathrm{C}$ for two minutes, $72^{\circ} \mathrm{C}$ for three minutes $\times 40$ cycles, with a final extension set for $72{ }^{\circ} \mathrm{C}$ for five minutes. Similar conditions were applied for EBNA-1 PCR.

For general primer PCR, amplification conditions were similar except $3.5 \mathrm{mM} \mathrm{MgCl}$ was used and an annealing temperature of $40^{\circ} \mathrm{C}$ was applied.

Type specific HPV PCR products were confirmed by dot blot hybridisation, as previously described. ${ }^{27}$

HPV AND EBV PCR-ISH

Sections of $3-5 \mu \mathrm{m}$ thickness (again selected from different areas of the tumour) were cut onto APES coated single well slides and placed on a hot plate for 12 to 16 hours. Section dewaxing was carried out as for normal in situ hybridisation. Proteinase digestion was carried out using $0.5 \mathrm{mg} / \mathrm{ml}$ proteinase $\mathrm{K}$ in proteinase $\mathrm{K}$ buffer as for in situ hybridisation at $37^{\circ} \mathrm{C}$ for 10 to 15 minutes. Blocking of endogenous alkaline phosphatase and peroxidase was carried out as above. Slides were then washed in PBS for five minutes. Tissues were amplified using the GeneAmp in situ PCR system 1000 (Perkin Elmer), which ensures maximal thermal kinetics. ${ }^{29} 30$

The PCR solution consisted of PCR buffer

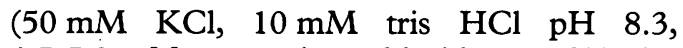
4.5-5.0 $\mathrm{mM}$ magnesium chloride, $0.01 \%$ gelatine, $200 \mu \mathrm{M}$ of each $\mathrm{dNTP}, 2 \mu \mathrm{M}$ each primer, 5 units of TaqIS $/ 50 \mu \mathrm{l}$, and $0.2 \%$ bovine serum albumin). HPV primers were as previously shown. ${ }^{27}$ EBNA-1 primers were as detailed above. A control reference gene, $\beta$ globin, was used to assess the efficiency of amplification. $\beta$ Globin primers were as follows: primer 1 (5'-ACACAACTGTGTTCACTAGC-3') and primer 2 (5'-CAACTTCATCCACG-TTCACC-3') and a biotinylated $\beta$ globin oligoprobe (5'-GACTCCTGAGGAGAAGTCTGCCGTTACTGC-3'). Slide assembly was achieved using Amplicover clips and discs and the slide assembly tool.

The following cycling parameters were applied: $94^{\circ} \mathrm{C}$ for six minutes followed by 40 cycles of $94^{\circ} \mathrm{C} \times$ one minute, $55^{\circ} \mathrm{C} \times$ two minutes. In addition, a separate extension step was included in some protocols but did not appear to yield better results. Following amplification, disassembly of the Amplicover clip and disc was performed. Slides were then carefully dipped in $100 \%$ alcohol to dehydrate and postfix the amplified product. In addition some slides underwent $2 \%$ paraformaldehyde postfixation for three to five minutes.

The amplified product was then detected using standard in situ hybridisation as described in the in situ hybridisation section, using an internal oligoprobe at $5-10 \mathrm{pmol} /$ $100 \mu \mathrm{l}$ of hybridisation mix containing $(2 \times$ SSC, $5 \%$ dextran sulphate, and $10 \%$ formamide).

Colorimetric detection was achieved using NBT/BCIP as for in situ hybridisation.

Appropriate controls used included fixed SiHa cells containing one to two copies of HPV 16, fixed CaSki cells containing 200 copies of HPV 16, and fixed P3HR1 cells containing EBV genome. For each assay the following PCR in situ hybridisation controls were included: (1) reference control gene $(\beta$ globin $)^{31}$; (2) no Taq DNA polymerase; (3) no primers; (4) primer 1 only; (5) primer 2 only; (6) target primers with an irrelevant probe (HHV 8); (7) irrelevant primers (that is, HHV8) with the target probe; (8) reference control gene primers ( $\beta$ globin/PDH) with the target probe.

\section{Results}

LOW GRADE GLANDULAR INTRAEPITHELIAL LESIONS

The age range of patients with glandular intraepithelial neoplasia examined was 26 to 40 years (mean 33.5 years). Results of the HPV analysis are given in table 1 .

By PCR, three of 10 cases were HPV 16 positive. NISH analysis confirmed these two positive cases, but extensive NISH analysis was not possible because of lack of adequate 
Table 1 Prevalence of human papillomavirus in endocervical lesions

\begin{tabular}{|c|c|c|c|c|c|c|c|c|c|c|c|}
\hline \multicolumn{6}{|c|}{ Non-isotopic in situ hybridisation } & \multicolumn{6}{|c|}{ Polymerase chain reaction } \\
\hline 6 & 11 & 16 & 18 & 31 & 33 & 6 & 11 & 16 & 18 & 31 & 33 \\
\hline \multicolumn{12}{|c|}{ Low grade GIN } \\
\hline NT & NT & $2 / 2^{\star}$ & NT & $0 / 10$ & NT & $0 / 10$ & $0 / 10$ & $3 / 10$ & $0 / 10$ & N/A & $0 / 10$ \\
\hline \multicolumn{12}{|c|}{ Adenocarcinoma and high grade GIN/ACIS combined } \\
\hline $0 / 8$ & $0 / 8$ & $2 / 8$ & $1 / 8$ & $0 / 8$ & 0.8 & $0 / 8$ & $0 / 8$ & $5 / 8$ & $2 / 8$ & N/A & $0 / 8$ \\
\hline \multicolumn{12}{|c|}{ Adenocarcinoma } \\
\hline $0 / 11$ & $0 / 11$ & $2 / 11$ & $1 / 11$ & $0 / 11$ & $0 / 11$ & $0 / 11$ & $0 / 11$ & $3 / 11$ & $1 / 11$ & N/A & $0 / 11$ \\
\hline
\end{tabular}

*Two residual samples showed evidence of GIN.

ACIS, adenocarcinoma in situ; GIN, glandular intraepithelial neoplasia; N/A, sequence not available for primer design; NT, no tissue available.

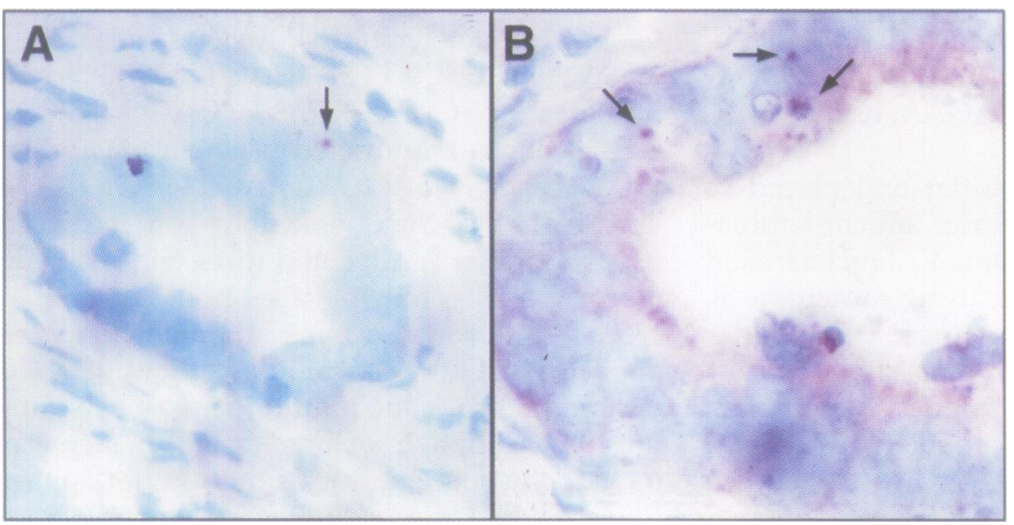

Figure 2 (A) NISH in adenocarcinoma in situ of the cervix showing HPV 16 in one cell nucleus. (B) HPV 16 PCR-ISH of a parallel section, showing two cells positive with a stronger intranuclear signal visible as compared to NISH. Notice also leakage of amplification product into the cell cytoplasm focally, which indicates minimal

overpermeabilisation.
ADENOCARCINOMA AND HIGH GRADE GLANDULAR INTRAEPITHELIAL NEOPLASIA/ADENOCARCINOMA IN SITU COMBINED

The age range of patients with adenocarcinoma and adenocarcinoma in situ combined was 38 to 48 years (mean 41.8 years). Results of the HPV analysis are given in table 1 .

By PCR analysis, five of eight and two of eight cases were HPV 16 and 18 positive, respectively. Coexistent CIN 2 was seen in three cases, all of which were HPV 16 positive.

By NISH, two of eight and one of eight cases were HPV 16 and 18 positive, respectively. The in situ hybridisation signal in HPV positive cases was punctate in all cases. In three of the cases (with high grade glandular intraepithelial lesions/adenocarcinoma in situ in relation to adenocarcinoma) both the intraepithelial lesion and adenocarcinoma were positive.

EBV was only identified by PCR in two cases, again subepithelial in location with no intraepithelial localisation seen.

The genotypic mapping experiment performed on six cases showed monotypic HPV types (that is, either 16 or 18) in each respective case. In three cases all four areas were HPV positive, in two cases two areas were HPV positive, and in one case only one area was positive by PCR analysis. NISH and PCR-ISH confirmed this geographical segregation. Low risk HPV types 6 and 11 were not identified in any of the cases.

\section{ADENOCARCINOMA}

histological material. Two HPV 16 positive cases had coexistent HPV 16 positive CIN 2 . EBV was identified in one case only, in subepithelial lymphocytes. No intraepithelial EBV signals were seen, either on NISH or PCR-ISH.

Of the two cases positive on NISH for HPV 16 , the in situ signal was punctate but tissue preservation was poor. PCR-ISH increased the signal intensity, and the number of cells positive in an individual dysplastic gland (fig 2).
The age range of patients with adenocarcinoma of the cervix was 36 to 63 years (mean 47.37 years). Results are illustrated in table 1 .

By PCR analysis, three of 11 and one of 11 cases were positive for HPV 16 and 18, respectively. Of the four cases positive by PCR, only two of four areas in each case were HPV positive on genotypic mapping, suggesting that the tumour was not clonal for HPV. NISH and PCR-ISH confirmed solution phase PCR data except in one HPV 16 case. No unsequenced

Table 2. Epidemiological data for adenocarcinoma of the cervix, adenocarcinoma in situ (ACIS), glandular intraepithelial neoplasia (GIN), and human papillomavirus (HPV) prevalence

\begin{tabular}{|c|c|c|c|c|c|c|c|c|c|}
\hline \multirow[b]{2}{*}{ Country } & \multirow[b]{2}{*}{ Method } & & \multicolumn{6}{|c|}{ HPV type (number of cases/number tested) } & \multirow[b]{2}{*}{ Reference No } \\
\hline & & & 6 & 11 & 16 & 18 & 31 & 33 & \\
\hline Ireland & PCR & $\begin{array}{l}\text { Adca } \\
\text { Adca + ACIS } \\
\text { Low grade GIN }\end{array}$ & $\begin{array}{l}0 / 11 \\
0 / 8 \\
0 / 10\end{array}$ & $\begin{array}{l}0 / 11 \\
0 / 8 \\
0 / 10\end{array}$ & $\begin{array}{l}3 / 11 \\
5 / 8 \\
3 / 10\end{array}$ & $\begin{array}{l}1 / 11 \\
2 / 8 \\
0 / 10\end{array}$ & $\begin{array}{l}0 / 11 \\
0 / 8 \\
0 / 10\end{array}$ & $\begin{array}{l}0 / 11 \\
0 / 8 \\
0 / 10\end{array}$ & \\
\hline UK & In situ & Adca + ACIS & $0 / 16$ & $0 / 16$ & $7 / 16$ & $4 / 16$ & $0 / 16$ & $0 / 16$ & 32 \\
\hline S Africa & In situ & $\begin{array}{l}\text { Adca + ACIS } \\
\text { ( } 6 \text { of the virus positive }\end{array}$ & $\begin{array}{l}0 / 22 \\
\text { carcir }\end{array}$ & $\begin{array}{l}0 / 22 \\
\text { las had }\end{array}$ & $\begin{array}{l}0 / 22 \\
\text { jacent }\end{array}$ & $\begin{array}{l}9 / 22 \\
\text { inoma ir }\end{array}$ & $\begin{array}{l}0 / 22 \\
\mathrm{cu})\end{array}$ & $0 / 22$ & 32 \\
\hline Denmark & In situ & $\begin{array}{l}\text { Adca } \\
\text { ACIS }\end{array}$ & $\begin{array}{l}- \\
-\end{array}$ & $\begin{array}{l}- \\
-\end{array}$ & $\begin{array}{l}4 / 11^{\star} \\
4 / 4^{\star}\end{array}$ & $\begin{array}{l}- \\
-\end{array}$ & $\begin{array}{l}- \\
-\end{array}$ & $\begin{array}{l}- \\
-\end{array}$ & $\begin{array}{l}33 \\
33\end{array}$ \\
\hline UK & In situ & (No HPV association) & & & & & & & \\
\hline USA & In situ & $\begin{array}{l}\text { Adca } \\
\text { ACIS } \\
\text { GIN }\end{array}$ & $\begin{array}{l}0 / 17 \\
0 / 7 \\
0 / 18\end{array}$ & $\begin{array}{l}- \\
- \\
-\end{array}$ & $\begin{array}{l}1 / 17 \\
0 / 18 \\
0 / 18\end{array}$ & $\begin{array}{l}16 / 17 \\
0 / 18 \\
0 / 18\end{array}$ & $\begin{array}{l}- \\
- \\
-\end{array}$ & $\begin{array}{l}- \\
- \\
-\end{array}$ & $\begin{array}{l}10 \\
10 \\
10\end{array}$ \\
\hline USA & $\begin{array}{l}\text { In situ } \\
\text { (mRNA) }\end{array}$ & ACIS & - & - & $4 / 13$ & $7 / 13$ & - & - & 37 \\
\hline
\end{tabular}

${ }^{\star}$ Combined data (HPV 16 and 18 )

ACIS, adenocarcinoma in situ; Adca, adenocarcinoma; GIN, glandular intraepithelial neoplasia. 
HPV types were identified using the pan HPV PCR approach. The data in this cohort again identified the tight restriction of HPV types 16 and 18 with the development of endocervical adenocarcinoma. EBV was only identified in one case by PCR, but not confirmed by NISH or PCR-ISH; this presumably was due to circulating infected B lymphocytes.

\section{Discussion}

The results of this study show a 30\% prevalence of the high risk HPV 16 in low grade glandular intraepithelial lesions (three of 10 cases). The results differ from those of Okagaki et $a l^{10}$ (see table 2), who did not identify HPV in low grade glandular intraepithelial neoplasia lesions, but are in agreement with the data from Jaworski's group. ${ }^{1}$

Our cohort of adenocarcinoma and high grade glandular intraepithelial neoplasia/ adenocarcinoma in situ combined showed five of eight and two of eight cases positive for HPV 16 and 18, respectively, by PCR (approximately $90 \%$ ). This mirrors the prevalence rates of HPV 16 and 18 for CIN grades 2 and 3 and invasive squamous cell carcinoma. Interestingly, only four of 11 adenocarcinoma cases (36\%) contained HPV 16 or 18, suggesting that HPV shedding occurs with time once tumour development has occurred. Our findings for HPV in adenocarcinoma and high grade glandular intraepithelial lesions/adenocarcinoma in situ are similar to those of Cooper et al who examined endocervical lesions in British and South African patients ${ }^{32}$ and to a smaller Danish study. ${ }^{33}$ Interestingly, Young et al were unable to identify any association between HPV and endocervical cancer, ${ }^{34}$ which is not in keeping with the broad body of evidence to date.

The prevalence of HPV 18 in our study is low as compared to Cooper's South African cohort and the series reported by Okagaki et al. ${ }^{1032}$ This may reflect geographical variations in HPV prevalence, which is supported by HPV prevalence in other systems. ${ }^{35} 36$

Using an mRNA analysis, Farnsworth identified HPV in 11 of 13 cases of adenocarcinoma in situ, with a predominance of HPV 18 (table 2). ${ }^{37}$

Genotypic mapping experiments carried out on adenocarcinomas in this study, showed that the majority of lesions did not contain HPV DNA sequences in all four areas sampled, indicating clearly that the tumour is not clonal for HPV. Importantly, no discordance between types was found in this analysis, suggesting that one and only one virus type (that is, 16 or 18) has the propensity to survive in such lesions. No mixed infections were identified, again in keeping with previous reports. Our data also confirm the absence of low risk HPV types 6 and 11 , which again is a constant finding in other studies, even accounting for geographical variations (table 2). The apparent segregation of HPV 16 and 18 with endocervical lesions points to some specific attribute of these viral types which are necessary for endocervical carcinogenesis. Perhaps the specific E6/E7 motifs in these types can interact in the development of endocervical cancer in a similar way to the recently described interaction between E6/7 ORFs of HPV 16 and human surface ovarian epithelial cells. ${ }^{38}$

We did not identify EBV in the epithelia of any of the lesions examined. PCR positivity was due to circulating positive infected $B$ cells. We conclude, therefore, that no link exists between HPV and EBV in the development of endocervical carcinoma. Its precise role in squamous cell carcinogenesis is not understood, but it appears that EBV can be found in squamous epithelial lesions. ${ }^{14} 232539-41$

In summary, HPV 16 and 18 appear to be involved in the pathogenesis of endocervical cancer from low grade glandular intraepithelial neoplasia to adenocarcinoma. We were unable to show any link between HPV and EBV in endocervical lesions. HPV infection is not clonal in endocervical cancer and coexistent adjacent CIN, where present, tends to show a similar HPV type. The restriction of HPV types 16 and 18 to endocervical lesions suggests that their effect is restricted and specific to endocervical mucosa, but currently the mechanism of interaction is unknown.

1 Jaworski RC. Endocervical glandular dysplasia, adenocarcinoma in situ and early invasive (microinvasive) adenocarcinoma of the uterine cervix. Semin Diagn Patho 1990;7:190-204

2 Shingleton HM, Gore H, Bradley DH, Twiggs LB, Ostrow RS, Faras AJ. Adenocarcinoma of the cervix. I. Clinica evaluation and pathologic features. Am $\mathcal{f}$ Obstet Gynecol 1981;139:799-814.

3 Tamimi HK, Figge DC. Adenocarcinoma of the uterine cervix. Gynecol Onccol 1982;13:335-44.

4 McKelvey JL, Goodlin RR. Adenoma malignum of the cervix. A cancer of deceptively innocent histological pattern. Cancer 1963;16:549-77.

5 Silverberg SG, Hurt WG. Minimal deviation adenocarcinoma ('adenoma malignum') of the cervix. A reappraisal. Am F Obstet Gynecol 1975;121:971-75.

6 Hasumi K, Ehrmann RL. Clear cell carcinoma of the uterine endocervix with in situ component. Cancer 1978;42: 2435-8.

7 Hart WR, Norris HJ. Mesonephric adenocarcinoma of the cervix. Cancer 1972;29:106-13.

8 Fox H, Wells M, Harris M, McWilliam LJ, Anderson GS. Enteric tumours of the lower female genital tract: report of three cases. Histopathology 1988;12:167-76.

9 Wells M, Brown LJR. Glandular lesions of the uterine cervix: the present state of our knowledge. Histopathology 1986:10:777-92.

10 Okagaki T, Tase T, Twiggs LB, Carson LF. Histogenesis of cervical adenocarcinoma with reference to human papillomavirus-18 as a carcinogen. $\mathscr{f}$ Reprod Med 1989;34 639-44.

11 Tase T, Okagaki T, Clark BA, Soong SJ. Human papillomavirus DNA In adenocarcinoma in situ, microinvasive adenocarcinoma of the uterine cervix and co-existing squamous intraepithelial neoplasia. Int $f$ Gynecol Pathol 1989;8:8-17.

12 Herrington CS. Human papilloma viruses and cervical neoplasia. I. Classification, virology and epidemiology. $7 \mathrm{Clin}$ plasia. I. Classification,

13 Arends MJ, Wyllie AH, Bird CC. Papillomavirus and human cancer. Hum Pathol 1990;21:686-9.

14 Landers RJ, O'Leary JJ, Crowley M, Healy I, Annis P, Burke $\mathrm{L}$, et al. Epstein Barr virus in pre-malignant and malignan lesions of the cervix. $\mathcal{F}$ Clin Pathol 1993;46:931-5.

15 Zur Hausen H. Human genital cancer: synergism between two virus infections, synergism between virus infections and initiating events. Lancet 1982;ii: 1370.

16 Zur Hausen H, Schulte-Holthausen H, Klein G, Henle G, Clifford P, Santesson L. EBV DNA in biopsies of Burkitt tumour and anaplastic carcinomas of the nasopharynx. Nature 1980;228:1956-8.

17 Nonoyoma $\mathrm{M}$, Huang $\mathrm{CH}$, Pagona JS, Klein G, Singh S. DNA of Epstein Barr virus detected in tissue of Burkitt's lymphoma and nasopharyngeal carcinoma. Proc Natl Acad lymphoma and nasophary 1973;70:3265-8.

18 Brickacek B, Hirsch I, Sibl O, Vilikusova E, Vonka V. Presence of Epstein Barr virus DNA in carcinoma of the palaence of Epstein Barr virus DNA in carcinoma

19 Raab-Traub N, Flynn K, Klein C. EBV DNA structure and oncogene expression in EBV associated malignancies. In Ablashi DV, Glaser R, Levine PH, Nonoyama M, Pearson GR, eds. Second international symposium on EBV and associated malignant diseases. London: Humana Press, 1987:423. 
20 Brickacek B, Hirsch I, Sibl O, Vilikosova E, Vonka V. Association of some supra glottic laryngeal carcinomas Association of some supra glottic laryng

21 Saemundsen AK, Albeck H, Hansen JP, Neilsen NH, Anuret M, Henle W, et al. Epstein Barr virus in nasopharyngeal and salivary gland carcinomas in Greenland Eskimos. $B r \mathcal{F}$ Cancer 1982;46:721-8.

22 Leyvraz S, Henle W, Chahinian AP, Perlman C, Klein G, Gordon RC, et al. Association of Epstein Barr virus with thymic carcinoma. N Engl f Med 1985;312:1296-9.

23 Sixbey JW, Vesterinen EH, Nedrud JG, Raab-Traub N, Walton LA, Pagano JS. Replication of Epstein-Barr virus in human epithelial cells infected in vitro. Nature 1983:306: $480-3$.

24 Young LS, Clark D, Sixbey JW, Rickinson AB. Epstein-Barr virus receptors on human pharyngeal epithelia. Lancet 1986; i:240-2.

25 Sixbey JW, Lemon SM, Pagano JS. A second site for Epstein-Barr virus shedding: the uterine cervix. Lancet 1986;ii:1122-4.

26 O'Leary J, Browne G, Crowley M, Healy I, Bashir MS, Lewis FA, et al. Non -isotopic detection of DNA in tissues. In: Levy ER, Herrington CS, eds. In-situ hybridisation. $A$ practical approach. Oxford: Oxford University Press, 1994: 51-83.

27 Arends MJ, Donaldson YK, Duvall E, Wyllie AH, Bird CC. HPV in full thickness cervical biopsies: high prevalence in CIN 2 and CIN 3 detected by a sensitive PCR method. $f$ Pathol 1991;165:301-9.

28 Van den Brule AJC, Snijders PJF, Gordijn RLJ, Bleker OP, Meijer CJLM, Walboomers JMM. General primermediated polymerase chain reaction permits the detection of sequenced and still unsequenced human papillomavirus genotypes in cervical scrapes and carcinomas. Int $\mathcal{f}$ Cancer 1990;45:644-9.

29 O'Leary JJ, Browne G, Johnson MI, Landers RJ, Crowley M, Healy IB, et al. PCR in-situ hybridisation detection of HPV 16 in fixed CaSki and fixed SiHa cells-an experimental model system $f$ Clin Pathol 1994;47:933-8.

30 Boshoff C, Schultz TF, Kennedy MM, Graham AK, Fisher C, Thomas A, et al. Kaposi's sarcoma associated herpes virus (KSHV) infects endothelial and spindle cells. Nature ved 1995;1:1274-8.
31 O'Leary JJ, Chetty R, Graham AK, McGee J O'D. In situ PCR: pathologists dream or nightmare? f Pathol 1996;178: 11-20.

32 Cooper K, Herrington CS, Lo ESF, Evans MF, McGee JO'D. Integration of human papillomavirus types 16 and 18 in cervical adenocarcinoma. $\mathcal{F}$ Clin Pathol 1992;45:3824.

33 Nielsen AL. Human papillomavirus type $16 / 18$ in uterine cervical adenocarinoma in situ and adenocarcinoma. A study by in situ hybridisation with biotinylated DNA study by in situ hybridisation
probes. Cancer 1990;65:2588-93.

34 Young FI, Ward LM, Brown LJR. Absence of human papillomavirus in cervical adenocarcinoma determined by in situ hybridisation. F Clin Pathol 1991;44:340-1.

35 Anwar K, Nakakuki K, Shiraishi T, Naiki H, Yatani R, Inuzuka $M$. Presence of ras oncogene mutations and human papillomavirus DNA in human prostate carcinomas. Cancer Res 1992;52:5991-6.

36 Efferet PJ, Frye RA, Neubauer A, Liu ET, Walther PJ. Human papillomavirus types 16 and 18 are not involved in human prostate carcinogenesis: analysis of archival human prostate cancer specimens by differential polymerase chain reaction. F Urol 1992;147:192-6.

37 Farnsworth A, Laverty C, Stoler MH. Human papillomavirus messenger RNA expression in adenocarcinoma in situ of the uterine cervix. Int F Gynecol Pathol 1989;8:321-30.

38 Tsao SW, Mok SC, Fey EG, Fletcher JA, Wan TS, Chew $\mathrm{EC}$, et al. Characterisation of human ovarian surface epithelial cells immortalised by human papilloma viral oncogenes (HPV-E6E7 ORFs). Exp Cell Res 1995;218: oncogenes

39 van den Brule AJC, Walboomers JMM, Meijer CJLM. Epstein Barr viral infection as a cofactor in cervical carcinogenesis. $\mathcal{F}$ Pathol 1995;176:219-20.

40 Se-Thoe SY, Wong KK, Pathmanathan R, Sam CK, Cheng HM, Prasad U. Elevated secretory IgA antibodies to Epstein Barr Virus (EBV) and presence of EBV DNA and EBV receptors in patients with cervical carcinoma. Gynecol Oncol 1993;50:168-72.

41 Wong KY, Collins RJ, Srivastava G, Pittaluga S, Cheung AN, Wong LC. Epstein Barr virus in carcinoma of the cervix. Int $\mathcal{f}$ Gynecol Pathol 1993;12:224-7. 